Received: 20/12/2020 --- Accepted: 03/02/2021 --- Published: 12/04/2021

THE CONSUMER ON SOCIAL NETWORKS AND BRAND PERCEPTION ANALYSIS

\title{
ANÁLISIS DEL CONSUMIDOR EN REDES SOCIALES Y SU PERCEPCIÓN DE LAS MARCAS
}

\author{
Beatriz Fernández De Bordóns: Complutense University of Madrid. Spain \\ bfernan12@ucm.es
}

José Ignacio Niño González: Complutense University of Madrid. Spain josenino@ucm.es

\section{How to cite the article:}

Fernández De Bordóns, B. y Niño González, J. I. (2021). The consumer on social networks and brand perception analysis. Revista de Comunicación de la SEECI, 54, 21-54. http://doi.org/10.15198/seeci.2021.54.e628

\section{ABSTRACT}

The use of social networks has proliferated in recent years. Although it is a very recent phenomenon, there are more and more types of networks used for different purposes. This is a review of the results of different researches carried out around this social phenomenon in Spain. To introduce the context this study retrieves a historical retrospective from the origins of social networks in the US at the end of the last century until today. The analysis begins with the results of the IAB Spain research "Situation on Social Networks 2019". The main conclusions are compared with those obtained from the research on social networks carried out by Publicis Media to understand consumer habits in this environment "Discovering Social Networks: Map of Consumption and use in Spain 2019". This followed by a comparative analysis of the results of both research, focusing on Social Network trends and an in-depth study on the most popular social platforms in Spain: Youtube, Facebook, Instagram, WhatsApp, and Twitter. Although social networks are perceived as platforms for young people, there is a very high consumption in the profiles called "perennials", which respond to a behavioral or attitudinal profile rather than a sociodemographic one. To conclude this reflection there is a focus on advertising in Social Networks, analyzing the perception of users and the behavior of brands as recorded in the "VII Observatory of Brands in Social Networks" published in 2019 by IAB Spain. 
Fernandez De Bordóns, B. y Niño González, J I. The consumer on social networks and brand perception analysis

KEYWORDS: Social Networks - Consumer - Trends - Brand - Awareness - Digital Advertising

\section{RESUMEN}

El uso de las redes sociales ha proliferado en los últimos años. Aunque es un fenómeno social muy reciente cada vez hay más tipologías de redes que se utilizan con distintos fines. En este trabajo se realiza una revisión de los resultados de varias investigaciones realizadas en torno a este fenómeno social y, en particular, su situación en España. Para situar el contexto se recoge una retrospectiva histórica desde sus orígenes en Estados Unidos a finales del siglo pasado hasta la actualidad. El estudio comienza por una referencia sectorial del "Estudio Anual sobre Redes Sociales 2019" realizado por IAB Spain. Estos resultados se comparan con los obtenidos de la investigación sobre redes sociales realizada por Publicis Media para entender los hábitos del consumidor en este entorno "Descubriendo las Redes Sociales: Mapa de Consumo y uso en España 2019". Se valoran los resultados de ambas investigaciones y se analizan las tendencias en el uso de las Redes Sociales con un estudio en profundidad sobre las plataformas sociales de mayor uso en España: Youtube, Facebook, Instagram, WhatsApp y Twitter. Aunque las redes sociales se perciben como plataformas dirigidas jóvenes, se demostrará cómo hay un consumo muy elevado en los perfiles denominados perenials, que responden a un perfil comportamental o actitudinal más que sociodemográfico. Para finalizar este análisis, se realiza un foco sobre la publicidad en Redes Sociales, analizando la percepción de los usuarios y el comportamiento de las marcas según se recoge en el "VII Observatorio de las Marcas en Redes Sociales" publicado en 2019 por IAB Spain.

PALABRAS ClAVE: Redes Sociales - Consumidor - Tendencias - Marcas Percepción - Publicidad - Digital

\section{ANÁLISE DO CONSUMIDOR NAS REDES SOCIAIS E SUA PERCEPÇÃO DAS MARCAS}

\section{RESUMO:}

O uso das redes sociais têm se proliferado nos últimos anos. Embora seja um fenômeno social muito recente, cada vez existem mais tipologias de redes são usadas com fins distintos. Neste trabalho se realiza uma revisão dos resultados de várias pesquisas realizadas sobre este fenômeno social e, em particular, sua situação na Espanha. Para contextualizar faz-se uma retrospectiva histórica desde suas origens nos Estados Unidos até finais do século passado à atualidade. 0 estudo começa por uma referência setorial do "Estudio Anual sobre Redes Sociales 2019" feito pela IAB Spain. Estes resultados se comparam com os obtidos da pesquisa sobre redes sociais realizada pela Publicis Media para entender os hábitos do consumidor neste entorno "Descubriendo las Redes Sociales: Mapa de Consumo y uso en España 2019". Se evidenciam os resultados de ambas pesquisas e se analisam as tendências no uso das Redes Sociais com um estudo aprofundado sobre as plataformas sociais de maior uso na Espanha: Youtube, Facebook, Instagram, WhatsApp e Twitter. Embora as redes sociais se percebam como plataformas 
Fernandez De Bordóns, B. y Niño González, J I. The consumer on social networks and brand perception analysis

dirigidas aos jovens, se irá demonstrar que existe um consumo muito elevado nos perfis denominados perennials, que respondem a um perfil comportamental ou atitudinal mais que sociodemográfico. Para finalizar esta análise, foi feito um foco na publicidade das Redes Sociais, analisando a percepção dos usuários e o comportamento das marcas segundo é feito no "VII Observatorio de las Marcas en Redes Sociales" publicado em 2019 pela IAB Spain.

Translation by Paula González (Universidad Católica Andrés Bello, Venezuela)

\section{INTRODUCTION: DEFINITION AND HISTORY OF SOCIAL MEDIA AND THEIR CURRENT TRENDS}

In 2016, the Royal Spanish Academy defined social networks as a "digital platform for global communication that connects a large number of users". According to the Social Networks Commission of the IAB Spain 2018, "social networks must meet the following requirements: (1) be a network of contacts, (2) have a profile, (3) allow interaction, and (4) offer social functionalities to interact with content (create, share, and/or participate)", as stated in the "Annual Study of Social Networks 2019 "(IAB Spain, 2019).

Social networks are defined by Boyd \& Ellison (2007) as "websites or webpages based on services that allow individuals (1) to build a public or semi-public profile on a closed platform, (2) to articulate a list of users to share the connection, (3) view and navigate their list of contacts and those made by others within the System. The nature and nomenclature of these connections vary on different social networks".

The visibility of the profiles, according to Boyd \& Ellison (2007), varies according to the social network and the user's discretion. By default, contacts are visible through search engines regardless of whether the user viewing the information has an account on the said social network. Facebook has a different approach since it only allows you to view the user's profiles of your network as long as they have not denied access permission. Once a user joins a social network, they are asked to identify users within the network with whom they have a relationship. The types of relationships are different depending on the social network: "friends", "contacts", "fans", or "followers".

Although social networks are a very recent social phenomenon, it is necessary to do a retrospective of how this mass phenomenon emerged. The origin can be established in 1995 when Randy Conrads founded www.classmates.com, a website that sought to ensure that former classmates from school, high school, or university could keep in touch after completing their studies or recover lost relationships (Brunetta, 2013).

From this moment, the use of social networks increased exponentially and in 1997 the SixDegrees social network appeared, which is based on the Theory of the Six Degrees that maintains that every person on the planet is connected or related to any other person by a chain that does not have more than five intermediate people 
and, therefore, both people are connected by six or fewer links (Martínez, Noguera, and Grandío, 2011). Boyd and Ellison, (2007) collect the history of social networks in their article "Social Network Sites: Definition, History, and Scholarship", and for these authors, SixDegrees.com was the first social network that allowed the creation of user-profiles and from 1998 create the network of friends. SixDegrees is created as a tool to help people connect with others and send messages to each other. SixDegrees attracted millions of users but failed as a sustainable business in 2000 when it closed its service. It was a business ahead of its time and had some establishment problems. Early adopters complained that little could be done once the friend request was accepted and, on the other hand, most users were unwilling to meet strangers.

From 1997 to 2001, many communities began to promote the use of contact or friend platforms: AsianAvenue, BlackPlanet, or MiGente allowed users to create personal, professional, or dating profiles.

The next wave of social media began when Ryze.com launched in 2001 to help people build professional networks. The platform is launched to connect entrepreneurs from the tech community around San Francisco including entrepreneurs, businessmen, and investors. Similarly, LinkedIn is launched as a professional network, consolidating itself as the most powerful business contact service and the global market leader today.

Later in 2003, MySpace was launched in Santa Monica, California, with hundreds of thousands of Silicon Valley users. Initially, it was competing with Friendster, Xanga, and AsianAvenue, but it quickly specializes in a network around music groups and stays focused on that content without having a massive diffusion.

Facebook began in early 2004 as an exclusive network for Harvard University students, and only admitted students who had an email account with the university's address @harvard.edu. Facebook began to support other universities while remaining a private community by requiring users to have the university's email address. In September 2005, Facebook expands to include "high school' students only upon approval of the student network administrator. Later, it launched the service for professionals within corporate networks, and then it was opened to all Internet users.

Since the launch of the Facebook phenomenon in 2004 until today, a multitude of social network brands have been created to cover different purposes and services for users of social networks, the first and most consolidated YouTube in 2006 and Twitter in 2006, although, afterward, many more have emerged.

Nowadays, social networks are used within different contexts, the importance they have as advertising communication vehicles is very relevant, and in which creativity is shown as a priority variable to reach the engagement potential of these platforms (Lee \& Hong, 2016). Commercial brands make real efforts to attract users and build a lasting loyalty relationship (Godey, Manthiou, Pederzoli, Rokka, Aiello, Donvito, \& 
Fernandez De Bordóns, B. y Niño González, J I. The consumer on social networks and brand perception analysis

Singh, 2016) since social networks have become a natural forum in which to discuss products and services with friends and family (Erkan \& Evans, 2016). However, the growth of social networks is centered on their progressive use as social communication platforms, with WhatsApp being the maximum exponent of this trend in our country today.

We see that networks can be classified as professional, general, and specialized (Celaya, 2011), while for Burgueño (2009) the taxonomy is broader, being able to be structured according to the target audience and the topic, the main subject of the relationship, its geographic location, or its platform.

According to the qualitative study carried out by Publicis Media in 2019, "Discovering Social Networks: Map of Consumption and Use in Spain 2019", the social networks that are currently used in Spain are classified according to the categories of services and their contents in different typologies:
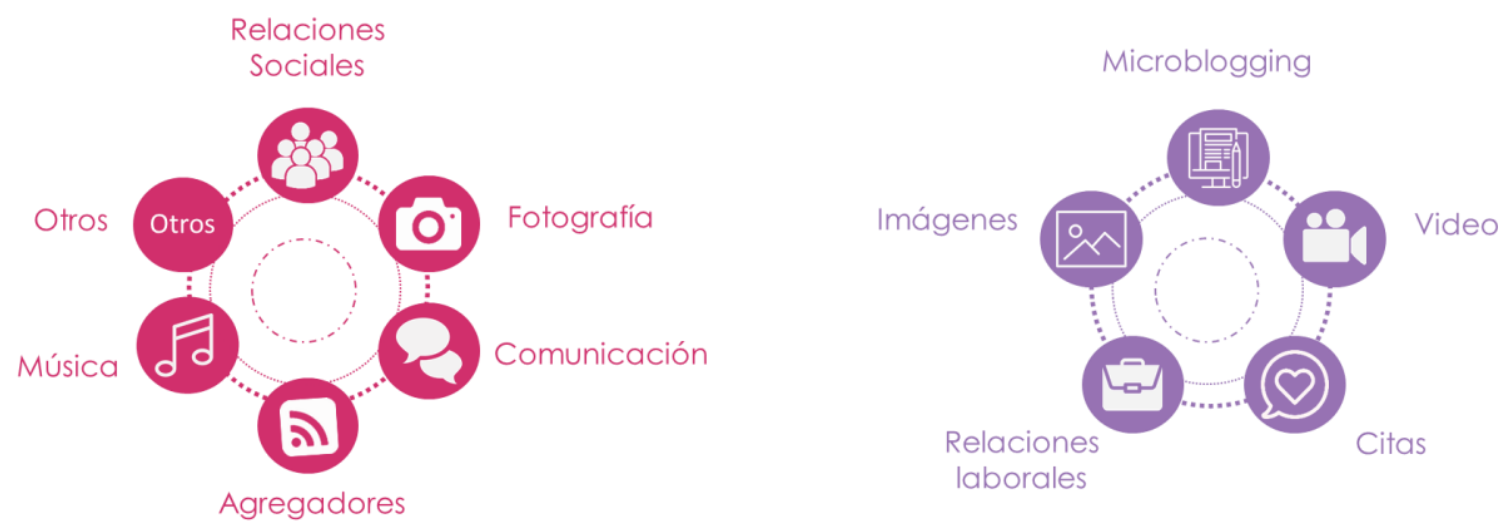

Image 1: Classification of the typology of Social Networks in Spain Source: Publicis Media (2019)

There are social networks for different types of content, use, and audiences. In this Publicis Media report, the main social networks used in Spain are listed, classified by network typologies based on their content: 


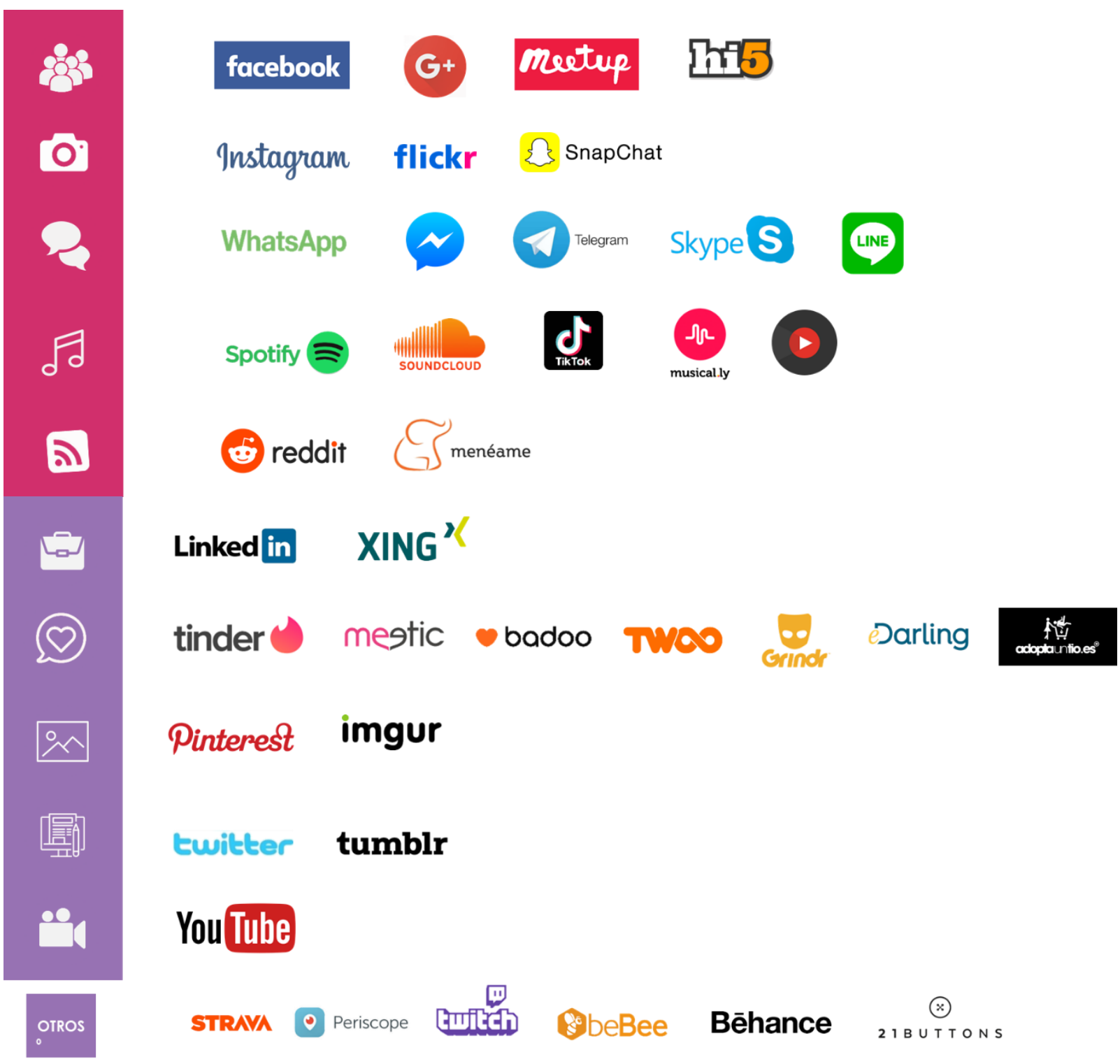

Image 2: Classification of Social Networks in Spain by their content Source: Publicis Media (2019)

From the advertising point of view, in social networks communication is carried out in a somewhat different way than in other digital platforms. There are specific codes and formats with metrics that are different even by type or platform. As stated in Chapter 6 The measurement of online advertising in the book "Digital Advertising: Towards an integration of planning, creation, and measurement" (Martinez, E., and Nicolás, MA, 2016, p. 115)," Social networks have generated a new way of managing advertising strategy and investment; through them and each one with its particularity, marketing is done with its advertising spaces which can be optimized based on metrics and ratios different from other types of channels".

This is how the book continues to collect, on page 116, the networks that have a very sophisticated level of segmentation due to the large amount of declarative information they obtain voluntarily through their users, and also the information they 
obtain from their profiles regarding their likes or lifestyles. The different networks manage their advertising spaces on their exclusive platforms. Thus, advertisement on Facebook is managed through its network, Facebook Ads. Twitter has a network for companies in which it offers various campaign models based on their objectives and cost models. LinkedIn also has its LinkedIn Ads network in which it markets its spaces to an exclusively professional audience. Lastly, Martinez and Nicolás, "Instagram, for example, since September 2015, has already introduced advertising in the network of celebrities par excellence. It has become a word of mouth network in photography + post mode in which recommendation marketing is done. Now, you can also sponsor products, brands, or services", conclude the authors.

Therefore, social networks have become a benchmark in digital advertising widely analyzed by the industry. Thus, the IAB annually conducts several studies of Social Networks and also includes this phenomenon among the main digital trends of recent years.

Social Networks are among the 15 digital trends, according to the report on "Top Digital Trends 2019" carried out by IAB Spain. The latest developments in Social Networks are the focus on video or social TV content, which allow you to view web series, news, events, or live shows in real-time, some are even created specifically for this environment.

Within Social Networks, the figure that is taking more prominence is the Influencer, as a prescriber of products, services, or content. Brands have begun to use these influencers as the fastest and most effective way to access younger target audiences more likely to listen to other users who upload their own content to social platforms, whether they are known influencers or not so well known. IAB points out as a trend of 2019 the appearance of virtual influencers, artificially created characters that have become popular on the Internet and that offer you advice and recommendations on various topics.

Within the networks, private messaging systems between groups of people are succeeding through chats such as WhatsApp or Line, even Facebook messenger. The newest trend is the use of these platforms as advertising support to reach the user while it is communicating with its contacts.

The last two trends highlighted by IAB in its 2019 Digital Trends report are Social Employee Advocacy and social login. Social Employee Advocacy is the work carried out by the professionals of a company to spread news of their company, generating a direct impact on the reputation of the brand. While social login refers to the ability of social networks to collect data from their users to build audience groups based on their social profile to later use it as an audience segmentation criteria in brand communication campaigns.

There are many utilities that Social Networks have for users that are part of them and for brands. That is why IAB, the main international association that integrates all the agents that operate in the digital world, has carried out not only an X-ray of the 
Fernandez De Bordóns, B. y Niño González, J I. The consumer on social networks and brand perception analysis

consumer in the Annual Study of Social Networks 2019 but also maintains every year an observatory of the activity of brands and the perception that users have of them on Social Networks.

\section{OBJECTIVES}

This article analyzes the phenomenon of social networks in Spain and the perception of advertising on these platforms. To understand this phenomenon, it is based on data extracted from the most current studies published about Social Networks in Spain. The article collects in an integrated way the basic information to understand this phenomenon. It begins with the definition of networks, performs a historical retrospective of their evolution, and collects the most up-to-date data to analyze the profile and use of Social Networks, especially for advertising purposes. Its main contribution is to demystify the belief that these social environments are only used by the younger generations, but are used by profiles of different ages that correspond to a mixed or combined segmentation of profiles based on multiple criteria, behavioral, contextual, temporary, according to the moments of their life's stage and their needs. It also evaluates the use of different social networks for different uses and by different user profiles.

The main Social Networks studies that are analyzed are those carried out by Publicis Media "Discovering social networks: Map of Consumption and Use in Spain 2019" and those of IAB Spain, the Report "Annual Study on Social Networks 2019" and the "VII Observatory of brands in Social Networks". Among all these reports, a very complete X-ray of the current dimension of this social phenomenon, user profiles, knowledge of social networks, and their coverage is carried out, analyzing the stages, channels, elements, motivations, and expectations that determine the moments of use of social networks and crossing this information with the main axes of their consumption, penetration, use by type of device, hours of the day, etc. As well as the advantages and disadvantages that stop the use of these platforms, and delves into the perception of users of the use of networks regarding the privacy of their data, what they share, what they search, the activity of influencers, and how all this content and activity, generated by the user, is used by brands to impact users of social networks with highly segmented communications and promotions through specific advertising platforms.

The review study concludes with more in-depth analysis, from the perspective of brands, which delves into the use of Social Networks by advertisers as an advertising platform for their brands and the phenomenon of influencers. All of this is analyzed with the results of the study carried out by IAB, "VII Observatory of Brands in Social Networks 2019', which collects the activity Top 100 brands extracted from the investment ranking per advertiser of Infoadex in 2018 in social networks. The categorization of these brands is based on the Study of Advertising Investment in Digital Media carried out by IAB Spain, which allows data to be crossed between both studies and maintains the coherence of the sectors analyzed in previous editions. 
Finally, an X-ray of social networks is made with the main conclusions about the use of social networks and advertisement, combining all the lessons learned from the analyzed market studies.

\section{RESEARCH METHODOLOGY OF THE ANALYZED STUDIES}

The analyzed Spanish Studies of IAB Spain and Publicis Media on social networks are based on robust research methodologies with highly significant representation, that allow conclusions to be extrapolated to the entire Spanish population. We summarize below the methodologies with which each of the reviewed research has been carried out.

The Study "Discovering social networks: Map of Consumption and Use in Spain 2019' by Publicis Media consists of a qualitative phase to define the phenomenon and a quantitative phase to size it.

The qualitative phase, developed in January 2018, was attended by the online community made up of 20 users of social networks. Of them, 65\% are regular with an average age of 32 years, being $70 \%$ women and $30 \%$ men. The other $35 \%$ were occasional users of social networks with an average age of 39 years, of which $20 \%$ were women and $80 \%$ men. The evolution and habits in social networks, the motivations and emotionality behind online life, and the revolution of social networks: brands, influencers, etc. were analyzed over three days. The main objectives, to know their experience in the networks they used, their history, their image and positioning, the reasons for use of the declared and underlying social networks, the preferred contents, how they are, what they contribute, and the needs that they cover. Finally, they were asked about the use they make of brands on social networks, what is worth and what is not in the community, and what advertising is consumed and which is let pass.

Besides the study of the online community, 5 structured in-depth interviews were added, lasting more than one hour. They analyze the consumption habits of using social networks, the image and positioning, the motivations for use, the most valued content, to finish with the use made by brands of social networks, their opinion about influencers, Youtubers, and the perception of advertising, and their expectations on social networks.

In the quantitative phase, 7,671 individuals participated, from May to October 2018 , who reported their multi-device navigation. Of them, $50 \%$ were men and $50 \%$ women and showed the following sociodemographic distribution by age and social class: 
Fernandez De Bordóns, B. y Niño González, J I. The consumer on social networks and brand perception analysis

Table 1: Sociodemographic classification of the 7,671 individuals surveyed in the quantitative phase of the Study of Social Networks in Spain ${ }^{1}$

Edad media
18 a 24 años
25 a 34
35 a 44
45 a 54
55 a 64
65 o más

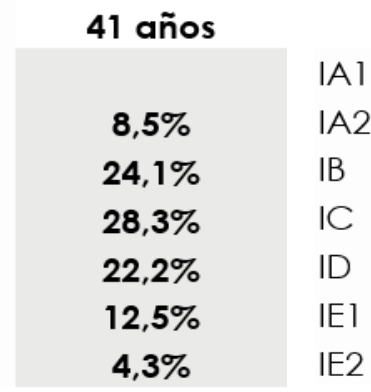

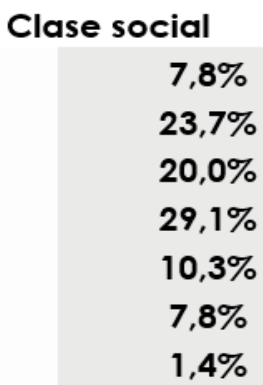

Source: Publicis Media (2019)

This study analyzes 38 social networks categorized into web and apps according to the classification included in the Introduction chapter, and used from different devices: PC, $98.6 \%$ of individuals, Smartphone $98.6 \%$, and Tablet $72.7 \%$. In this phase, consumption is described at a quantitative level, by the time of day and times of consumption, day of the week, and type of device. The types of users of the networks, the most used content by gender, and the contribution of each of the networks are also classified by making an infographic of the profile of the top 5 social networks.

For its part, the IAB Spain Report "Annual Study on Social Networks 2019' was carried out in February 2019, by the C.A.W.I. online self-administered computer interview with 1,313 men and women between the ages of 16 and 65, of whom 1,094 are users of social networks, 197 do not use them, and 156 professionals from the digital advertising industry. The data were weighted to represent the Spanish Internet population according to the ONTSI data.

${ }^{1}$ A new socioeconomic Classification system of the EGM (General Media Study by its acronym in
Spanish), prepared by the AIMC (Association for the Research of Media by its acronym in Spanish). In
2015 , the traditional classification of social class, existing since 1988, was updated, which valued the
level of studies and the profession, distributing them between High, Medium-High, Medium-Medium,
Medium-Low, and Low social class. This new system tries to represent the current structure of
household income, incorporating new variables: "The new classification combines 3 variables: 1 . the
original matrix (educational level and profession of the main breadwinner) with updated assignments,
2. The activity of the main breadwinner (Works, retired, unemployed, inactive), and 3. New variables
to take into account: household size and number of individuals with income in the household. The
combination of these three variables is the best estimator to rank households (and consequently
individuals) by income level". (AIMC, 2015, p. 3 Executive Summary New EGM Economic Classification
System retrieved from
rettps://www.aimc.es/a1mcc0nt3nt/uploads/2018/05/resumen info clas socioeconomica.pdf) 


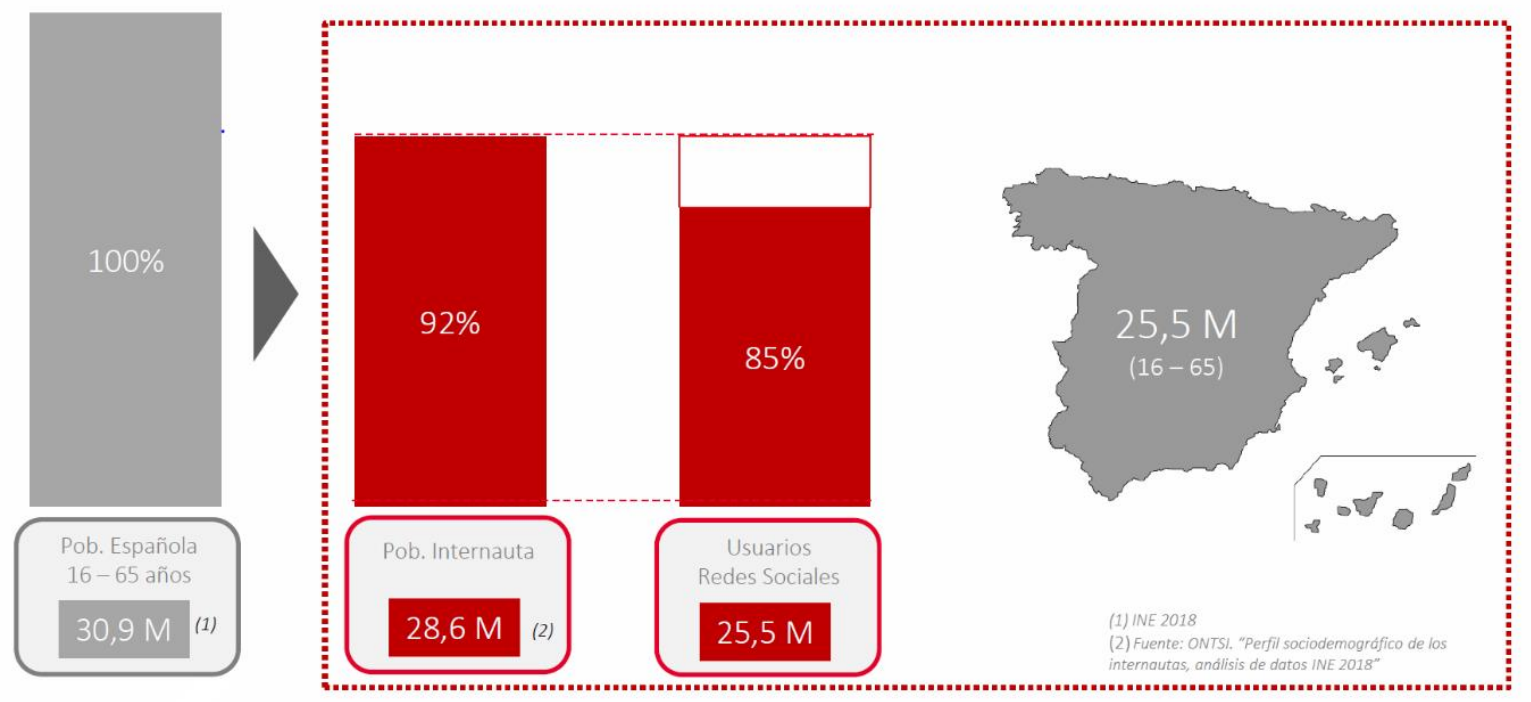

Image 3: Users of Social Networks in Spain.

Source: IAB Spain (2019)

This study quantifies the penetration and profile of social networks to understand their knowledge and use by sociodemographic profile, device, activities carried out, and the relationship between advertisement and social networks, the perception of influencers, and the opinion of professionals in the digital world is evaluated. It ends with the trends of the use of ephemeral videos and live-broadcasts through video streaming.

To conclude the "VII Observatory of Brands in Social Networks of 2019", was held for the first time in 2013, this being the VII edition that includes the activity of 92 brands in social networks divided by sectors and categories, in the period of a year from 2018 to 2019. The analysis of the activity of the brands is carried out on Facebook, Instagram, YouTube, and Twitter networks selected for the number of users they have, the presence of the brands, and the ability of the tools to control the metrics that are analyzed in the observatory.

To monitor these brands on the four social networks, a tool from Epsilon Technologies was used for a full year. The analysis period was from April $1^{\text {st }}, 2018$ to March $31^{\text {st }}, 2019$. The platform, which retrieves the data through APIs to the four platforms, applies a tool called Icarus that has an Artificial Intelligence technology through language to structure the data depending on the size of the networks' communities, the volume of interactions that take place, the number of shares made of the information that is published, and the efficiency of each of the social networks.

The study has carried out an analysis on the use of the best-known brands in each of the following categories: automotive, gaming and betting, food, beauty and hygiene, distribution, energy, finance and insurance, technology, telecommunications, travel, and government and politics. 
The main metrics analyzed in this study, complementary to the two previous ones, are the shares of the social network communities in terms of fans, followers, and subscribers, the number of posts and interactions, likes, comments, retweets, or sharing of posts. It also evaluates the type of publications according to the type of content: text, image, or video. The study concludes by evaluating the engagement measured by different types of interactions that are generated in each community, the virality, and the efficiency of the communication of the publications on social networks.

With these three research, based on very different methodologies, which evaluate different community criteria, it is possible to carry out an X-ray of social networks in Spain, study the profile of their users, and the effectiveness of advertising activity in this environment for commercial brands.

\section{DISCUSSION OF RESULTS}

\subsection{Characteristics of the Social Networks user's profiles}

The penetration of social networks in Spain has gone from $51 \%$ in 2009 to $85 \%$ in 2019 for people over 16 years of age, according to the "Annual Study of Social Networks 2019' (IAB Spain, 2019). The user profile on Social Networks in Spain is balanced between men and women $49 \% / 51 \%$, with the same share as the distribution of the social population in Spain. The average age is 39 years old, distributed by age groups as follows: $31 \%$ of users are between 16 and 30 years old, while $39 \%$ are between 31 and 45 , and $30 \%$ are between 45 and 65 years old. The Spanish population that uses social networks is becoming more mature and the most senior audiences have entered the platforms. However, curiously, the profile of nonusers of the networks is mostly male, $60 \%$, while only $40 \%$ are women and most have higher age ranges. Only $13 \%$ of young people between 16 and 30 years old do not access social networks. 


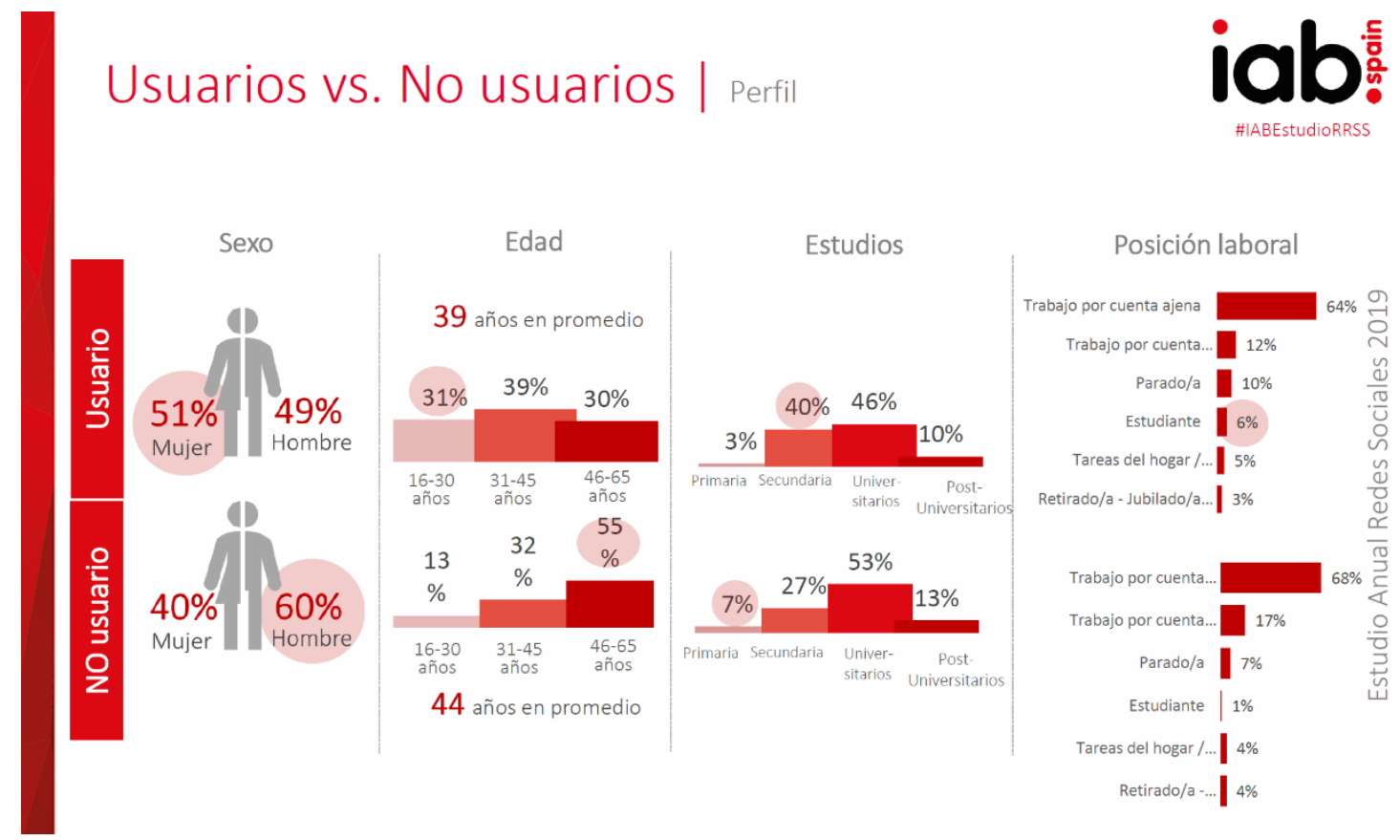

Image 4: Profile of users of Social Networks in Spain.

Source: IAB Spain (2019)

Both studies, IAB and Publicis Media, conclude that there are 5 large social networks whose penetration is very far from the rest, showing in both studies coverage percentages greater than $85 \%$. Logically, they coincide with the 5 networks with the highest suggested knowledge are Facebook (96\%), WhatsApp (93\%), Twitter $(87 \%)$, Instagram ( $84 \%)$, and followed by YouTube $(83 \%)$. The rest of the networks mentioned are recognized by less than $60 \%$ of the 1,094 surveyed by the IAB. This coincides with the coverage data of the 7,671 surveyed by Publicis Media, although the same 5 networks are cited and all of them are above $90 \%$, however, it appears in a different order than the suggested knowledge: YouTube appears as the leader with $99.6 \%$ coverage, Facebook with $99.4 \%$, WhatsApp goes from $2^{\text {nd }}$ to $3^{\text {rd }}$ place with $97.6 \%$, Instagram advances a position with $92.5 \%$ coverage, followed by Twitter which reaches $92.7 \%$.

Ratings of respondents in the IAB study:

- Facebook occupies leadership positions in coverage and knowledge.

- WhatsApp is the network with the largest number of users and the best rated.

- Instagram rising in users and consumption.

- Twitter occupies the $5^{\text {th }}$ position in all the Top5.

- YouTube remains among the top 5 , being the $2^{\text {nd }}$ best rated.

The consumption of social networks is multi-device, although in both studies mobile phones are shown as the most used device. According to Publicis Media, 3 out of 4 network connections are made from mobile phones, but the visits from the computer are longer than from other devices. And according to the IAB, mobile phones are the kings of social networks, $95 \%$ of users connect from mobile phones, 
especially high in the case of women. See data of the three devices and their evolution in the last 9 years.

\section{Dispositivo de conexión} - El móvil sigue siendo el principal dispositivo de acceso a redes sociales (95\%) con niveles muy
parecidos al de 2018. De todos modos, el ordenador es usado también de forma generalizada.
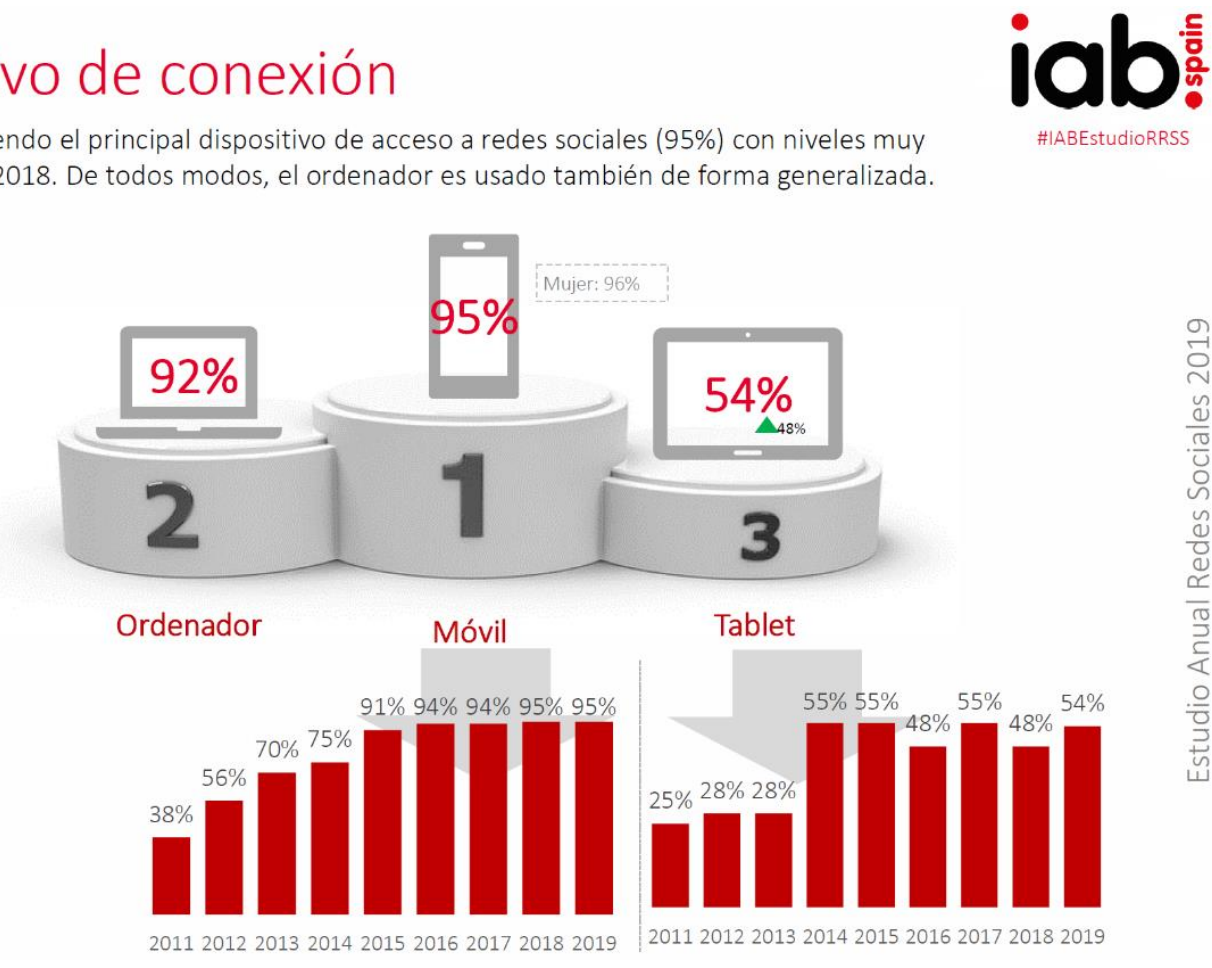

Image 5: Devices used to connect to Social Networks in Spain.

Source: IAB Spain (2019)

The average connection time to social networks per user and day is 1 hour and 13 minutes, with an average of 956 sessions per user, 159 per month, and 5 sessions per day of 14 minutes on average, as reflected in the results from the Publicis Media study.

Regarding the distribution of use by hours of the day, both studies show that consumption is quite homogeneous, from 12 to 24 hours consumption is quite high, and consumption is not differentiated by gender or type of device, and neither the number of visits nor the time of the sessions differs by range, remaining fairly stable in the most active times of the day. According to Publicis Media, there are also no significant differences in use throughout the week.

The times of consumption of social networks vary throughout the day, but the holidays do not differ much from the weekdays, according to Publicis Media.

This study concludes that network users can be grouped into three typologies:

1. Addicts, who spend more time on social networks, generally post a lot, and actively follow the posts of others.

2. Little active, who spend little time due to lack of interest or time.

3. Not active on social networks, but they do spend time chatting on WhatsApp. 
Although the users of the networks are equally represented by gender, the study by Publicis Media does show that there is a use of different types of networks according to gender. Being the aggregators and dating platforms, most used by men. However, women use image-sharing platforms more than men.

It also highlights that there is a greater time dedication to the 5 largest networks (Top 5) and that the consumption of the most minority networks is much more fragmented. But it is very clear that each network gives users something different. WhatsApp is mostly used for instant messaging, while Facebook, Instagram, and Twitter are used to connect with people, publish content, and get informed, and YouTube and Spotify to access audiovisual content.

\subsection{The types of Social Networks according to their content, profiles, and uses}

In the study "Discovering Social Networks" by Publicis Media, 2019, a qualitative and quantitative analysis is carried out of the 38 most-used social networks in Spain. Besides the 5 most-used networks, an in-depth comparative study and a file with the profile of their users are carried out. This information allows us to conclude the panorama of social networks in Spain through the main data of all of them.

For users surveyed by Publicis Media, Facebook and Instagram, both networks owned by Facebook, are the networks with the highest number of users, but they are used differently. Instagram stands out for the audiovisual content, photos, and videos that are used in stories, it is the best designed and the most liked as it is more visual. It allows making lives and this is used by Youtubers and influencers who have a large presence on this network and who publish a lot of trending content. For its part, Facebook is defined as the most complete at the content level.

Twitter is defined as the most credible network, with the least censorship, to access current news, and claim opinions and judgments. It is the fastest and most credible, unlike Facebook which, although it is more used for the content of a more personal nature, is the most used to distribute the so-called fake news.

LinkedIn is the network used for connections in the professional world. Although Facebook also allows you to post and share the posts of others, LinkedIn is considered a more serious network for professional use, while posts on Facebook are more personal.

Skype is the most recognized network for making video calls and is mainly used from the computer, while WhatsApp is considered the day-to-day communication network, and is mainly used from the mobile phone, although from the computer it allows you to upload stories and create groups or chats. Other social networks are used to share content and publications without having to have the phone number or know all the members of the group with which you communicate. 
YouTube is the image and video network and allows you to listen to audiovisual content of all kinds, humor, video blogs, live videos, music videos. It has a large presence of Youtubers and influencers and allows subscriptions to specific content channels.

Spotify is the social network for music. It has a fantastic library of artists, it is free to use with advertising and paid or Premium use without advertising. It allows you to follow authors or share music from other users.

It is very clear that each social network occupies a different place in the mind and use that consumers make of them.

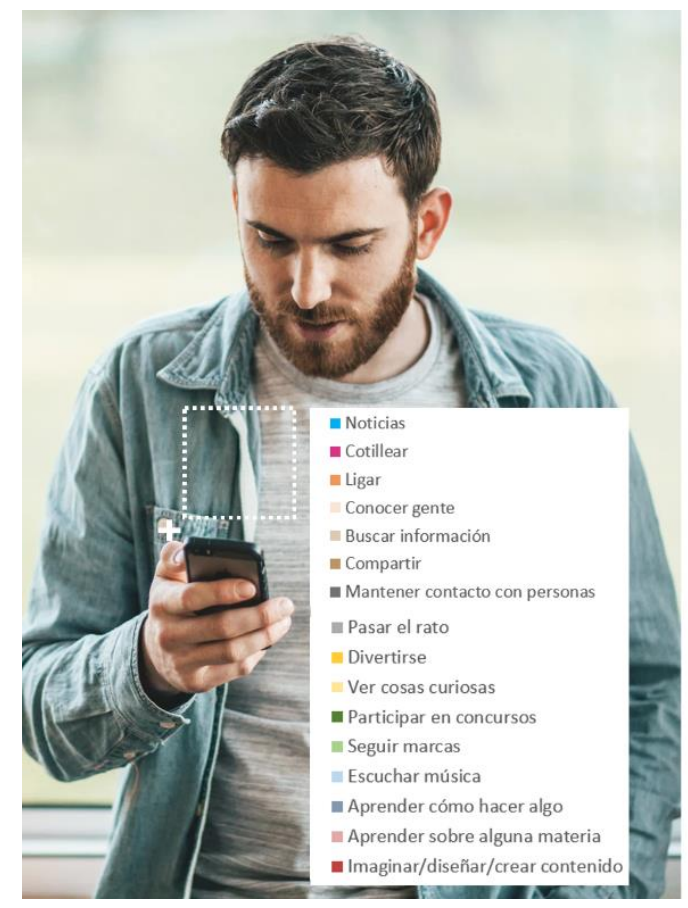

\section{Cada red social ocupa su lugar}

\section{¿QUÉ ES LO DESTACABLE DE CADA RED SOCIAL?}

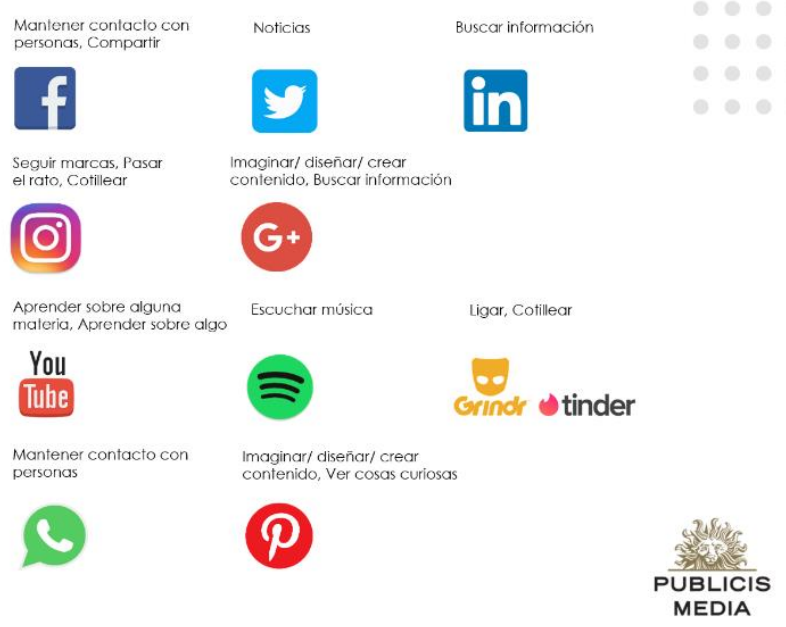

\section{Image 6: Use of each social network in Spain \\ Source: Publicis Media (2019)}

Next, we present the main profile data of each of the 5 main social networks in Spain: Facebook, Youtube, Twitter, Instagram, and WhatsApp. In the files made for each social network, valuable information is collected to understand the profile of the users and their behavior in each of these networks. The data of the unique user number, number of sessions per user, average duration of the visit, average time per user, the average age of the user, the distribution of consumption, by time range, days and months, as well as consumption by device type are displayed.

Facebook is the gateway to the first social network of many, familiar, close, and emotional in which you can find almost everyone. It is used mainly from the mobile app, it does not have prime time slots, it is used throughout the day, with frequent visits of 19 minutes a day. See usage diagram: 
Fernandez De Bordóns, B. y Niño González, J I. The consumer on social networks and brand perception analysis

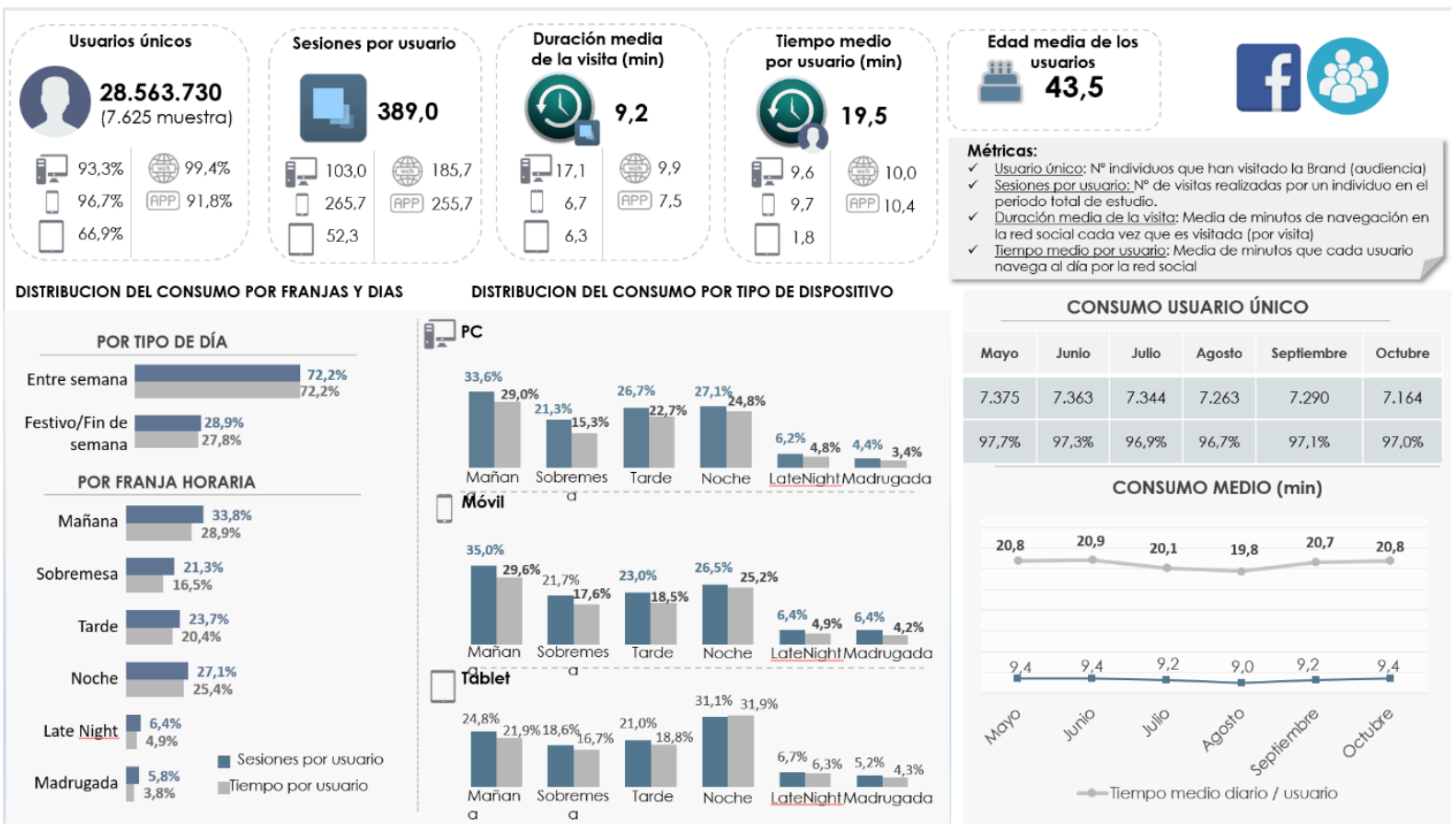

Image 7: Facebook usage profile in Spain

Source: Publicis Media (2019)

YouTube is recognized as TV 2.0. in which users consume audiovisual content as a source of knowledge and entertainment. It is not perceived as a social network. It is used mainly from the mobile phone, and its visits last about half an hour, it receives less frequency of visits, and the night is its prime time, although it is a dayto-day network with enough access stability.
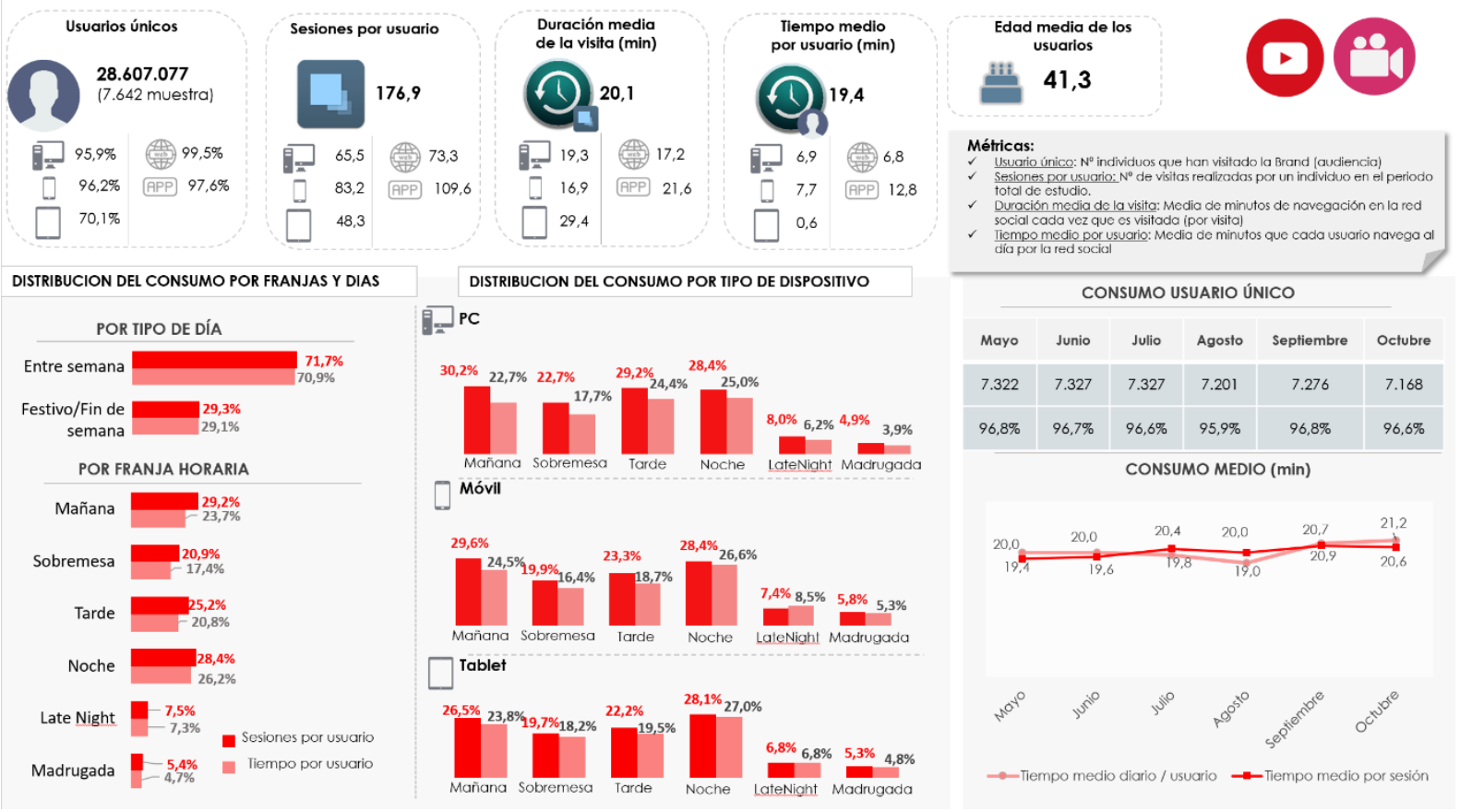
Fernandez De Bordóns, B. y Niño González, J I. The consumer on social networks and brand perception analysis

\section{Image 8: YouTube usage profile in Spain}

Source: Publicis Media (2019)

Twitter is defined as the network of immediacy, of the instantaneous connection with the news of any subject to know the opinion of the protagonists of the story or be able to give an opinion or be part of reality. It is mainly used from the mobile phone with daily frequency and an average of 4 minutes a day. It has more use in the morning perhaps for its informative nature.

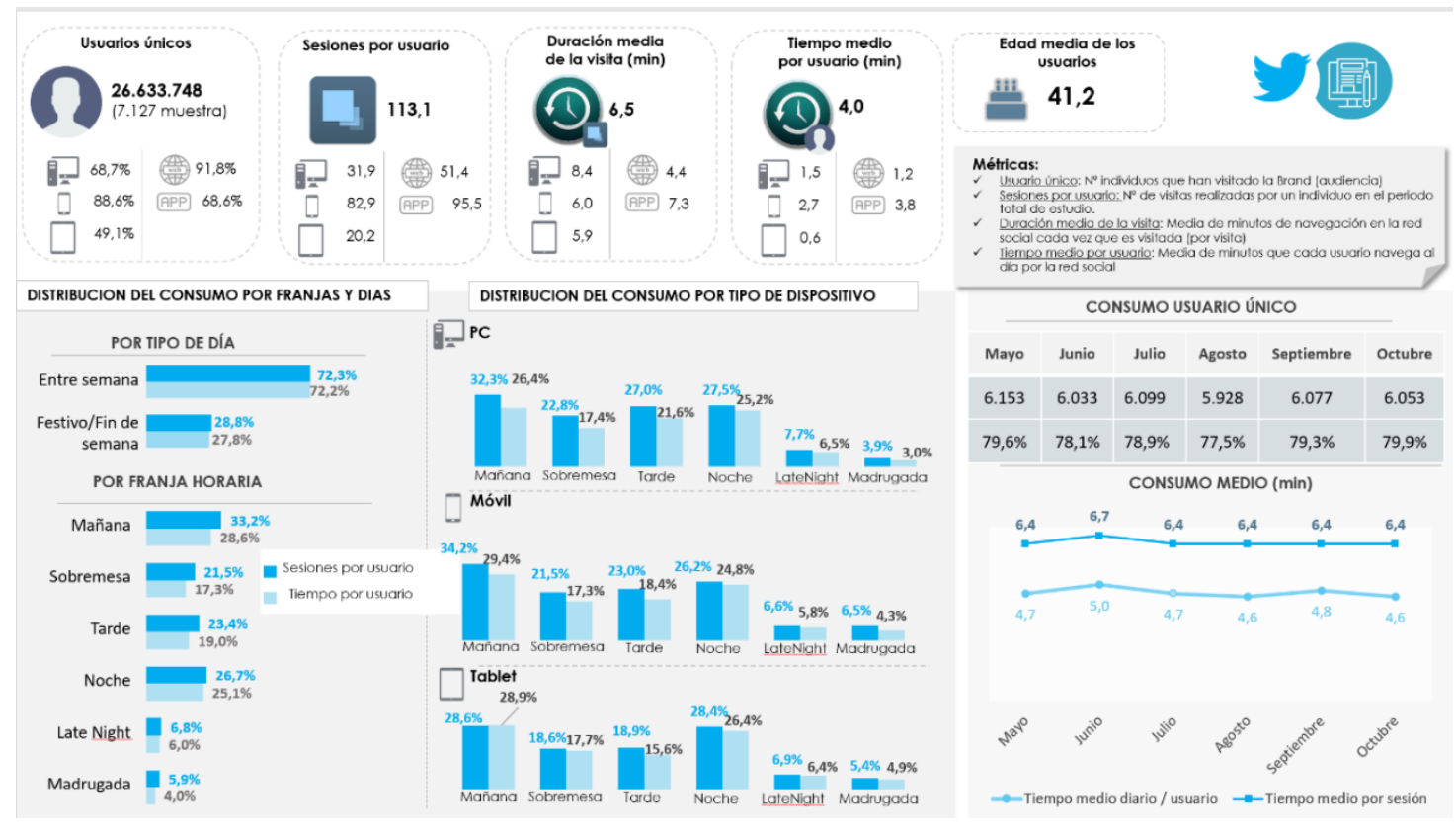

Image 9: Profile of Twitter usage in Spain

Source: Publicis Media (2019)

Instagram is the network for disconnection and evasion, the entertainment. It has three aspects: the artistic one, that of sharing and discovering places or things, and that of posing where the image of your life is presented and is used a lot to share memes. In it, you compete for the number of likes and it is perceived as a modern and current network. 
Fernandez De Bordóns, B. y Niño González, J I. The consumer on social networks and brand perception analysis

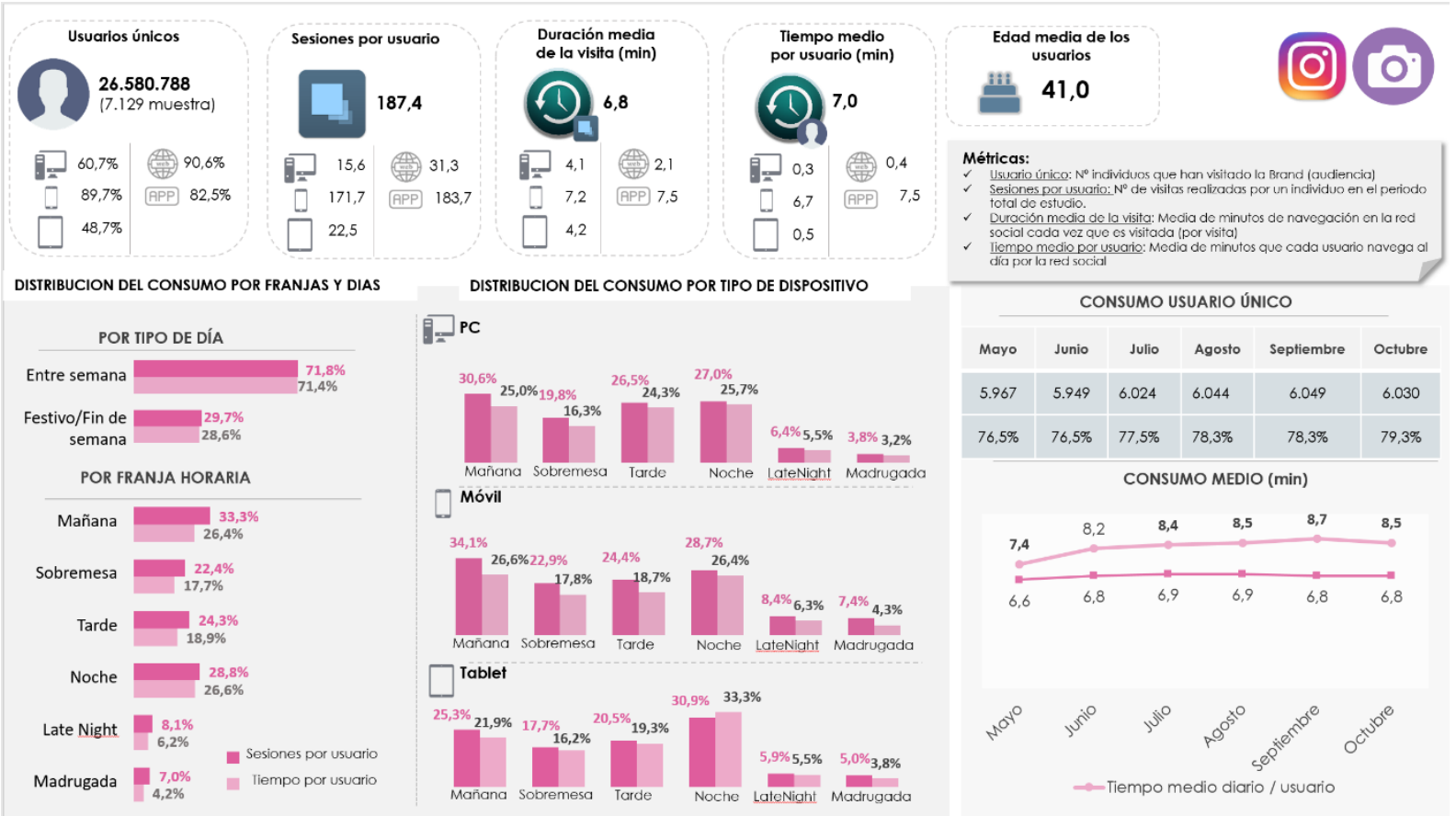

Image 10: Profile of Instagram usage in Spain

Source: Publicis Media (2019)

WhatsApp is the instant interpersonal communication network that everyone uses. The access device is the mobile phone, it is used all day, although a little more in the morning with very frequent accesses, and without a great dedication of time. And it is one of the main networks for the distribution of videos and memes.

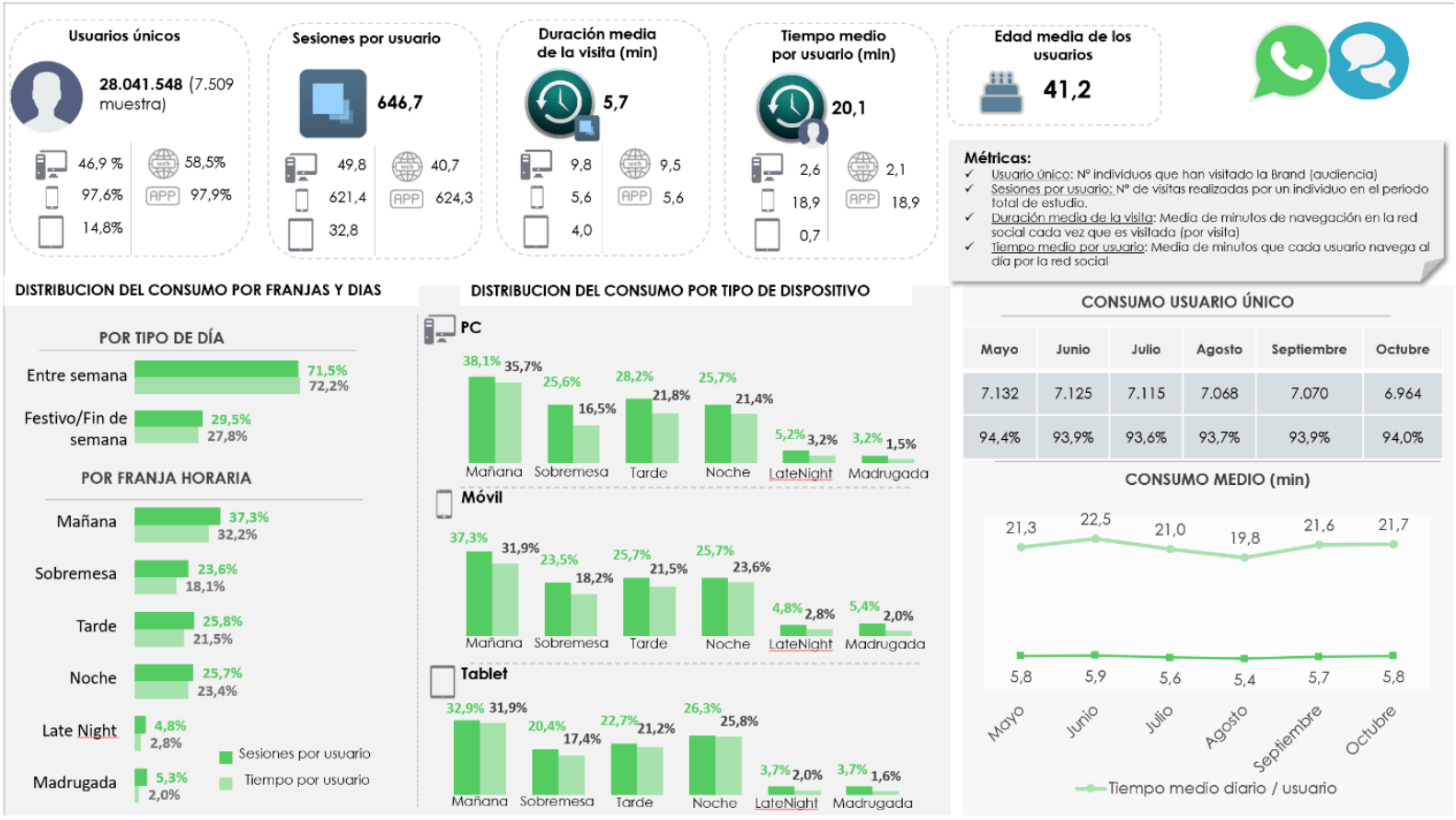

Image 11: WhatsApp usage profile in Spain

Source: Publicis Media (2019)

Revista de Comunicación de la SEECI. 2021, nº 54, 21-54 


\subsection{Users and usage preferences in Social Networks}

According to the Publicis Media study, users use the networks with clear preferences regarding content. Facebook is used more for restaurants, bars, sports, and hobbies, Twitter for politics and reading, Instagram for photography and fashion, LinkedIn for banking, YouTube for crafts, music, and games, Spotify for music, WhatsApp for hobbies, Pinterest for decoration and photography, and Tinder for entertainment.

The main reasons why social networks are used are personal contact with friends and loved ones, as well as to keep up to date, entertainment, seeking inspiration, as a form of expression, to gossip, or the use, for professional and employment purposes, of job search tools and professional and personal projection tools.

It is interesting to note that the topics that are read about on social networks are different from the topics that are published on the networks. We like to read and see everyday topics such as publications from friends, family, and acquaintances, content related to their hobbies, entertainment, and distraction, such as humorous and curiosity content, current news, film and television, celebrities, and influencers. In the professional field, networks are used both to search for job offers and to access content about their sector.

What we like to publish, according to the Publicis Media study, is very different from what we read. Regarding personal content, the daily life of each one is published through photos, stories, songs, etc. The professional content of the publication of materials related to the professional sector of each one and of a labor nature in general. Other types of content are shared: content for protest, criticism, and about social causes, curious content of news, and informative articles on interesting topics that arouse our curiosity, and relaxed content, entertainment, and humor, in which images, vignettes, and memes abound.

Users who publish content on the networks seek self-expression and search for approval, to express themselves, interact with others, seek their acceptance, and store content. When they do, they have a sense of pleasure, excitement, and euphoria.

The content is intended to be liked and successful, for which the impact that each publication of photos and videos is having is reviewed and controlled through likes, comments, etc., regardless of the type of publications they are, permanent or ephemeral, such as Instagram stories or WhatsApp statuses.

The greater the degree of interaction/involvement of the response, the more the user values it. For example, a share or an elaborate comment is more valued than a like.

Users are afraid of rejection and negative reviews when uploading a post. What is liked the least is the disrespectful and unconstructive tone against which users 
Fernandez De Bordóns, B. y Niño González, J I. The consumer on social networks and brand perception analysis

generally adopt three positions: ignore the comment, respond briefly and concisely, or respond with a long, elaborate, and well-argued text.

\subsection{Brands, advertising, and Social Networks}

After analyzing the consumers of Social Networks as an audience, their main use metrics, and the profiles of the Top 5, we delve into the use made by the brands of this channel as a means of communication.

According to the IAB Social Networks Study, $72 \%$ of the 1,094 respondents declare that they are a fan or follower of a brand. For $26 \%$ of them, brands that have social profiles inspire more trust, this percentage is higher in those under 45 years of age. $30 \%$ positively accept advertising and this acceptance is greater in those under 30 years of age. It also stands out that $48 \%$ consider that advertising meets their expectations and $30 \%$ very much like that advertising focuses on their interests, while $30 \%$ are bothered by advertising on social networks.

Social networks are effective in advertising actions. Regarding conversions or response to advertising on social networks, click rates are high by $20 \%$ and the frequency of clicks is also high, being higher in profiles between 16 and 30 years of age, according to data from the IAB 2019.

Social networks are an effective vehicle for connecting brands, especially with women and younger target audiences, under 45 years of age. 55\% make inquiries on social networks before making their purchases and $41 \%$ comment on their purchases. These inquiries are mainly on Facebook $63 \%$, YouTube $37 \%$, and Instagram $24 \%$. $64 \%$ positively value comments on social networks, $52 \%$ think they influence their decisions. Those who value it the most are women and those under 45 years of age.

According to the Publicis Media study, what brand users look for the most are photos of products, opinions of other users, information about the brand, giveaways, and promotions. The most successful social networks in the search for brand information are Instagram and Facebook, and they coincide with those that receive the most publicity.

Furthermore, most users do not perceive advertising as something negative as long as the amount of advertising is reasonable, non-intrusive, and does not prevent consuming the content of the page. There is widespread awareness about advertising as part of the business that helps these social networks work for free for the user. Brands use them to promote themselves and grow. The problem is associated with the consumption of data and the performance of the user's devices. Although they perceive the networks as quite safe places as long as they are used responsibly. They consider that the collection of their personal data is the price they pay for using social networks and privacy problems are prevented by selecting which content to share and blocking unwanted users. 
Fernandez De Bordóns, B. y Niño González, J I. The consumer on social networks and brand perception analysis

However, there is a minor group of users who perceive advertising on social networks as negative and annoying. They are aware that we live in a consuming society, but they consider that the amount of advertising is too much to the point of being invasive and intrusive.

According to the 156 professionals in the sector specialized in digital advertising consulted by IAB Spain, social networks are used for different purposes: to sell products and services $(79 \%)$, offer customer service $(56 \%)$, generate brand awareness $(51 \%)$, answer questions or inquiries from consumers $(51 \%)$, capture leads or contacts (50\%), and build brand image (47\%).

\section{Objetivos de las Redes Sociales |}

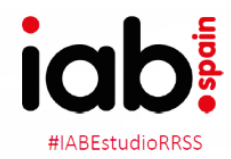

- El principal uso por parte de los profesionales de las Redes Sociales recae en vender, que aumenta en 12pp, seguido de ser un servicio de atención al cliente.

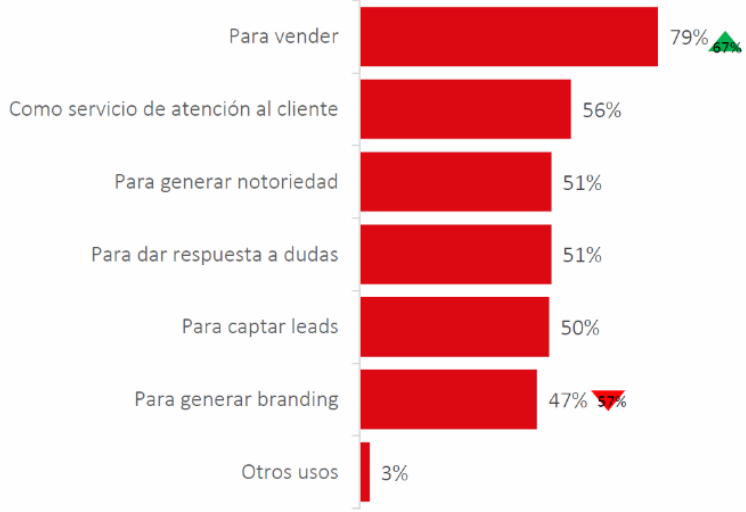

Image 12: The use of social networks by advertisers and their agencies Source: IAB Spain (2019)

Regarding the type of actions, these professionals declare to the IAB that promotions are the type of actions that work best on the networks, generating a greater number of interactions and visits to the web. 


\section{Contenidos en Redes Sociales |}

- Las promociones es el contenido que más generan en Redes Sociales y las que mayor número de interacciones y tráfico web generan.

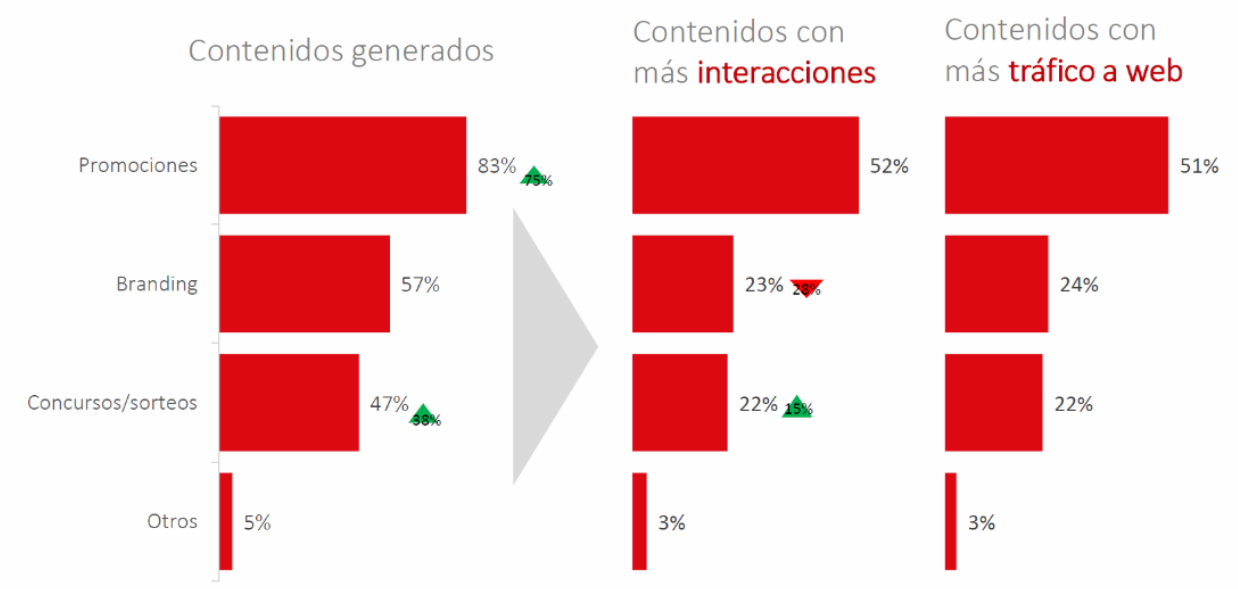

Image 13: The type of content and its results in social networks Source: IAB Spain (2019)

WhatsApp Business is a new advertising channel that brands use mainly to clarify doubts $82 \%$, manage orders $57 \%$, and send advertising $49 \%$.

Four of the five networks that receive the highest advertising investment coincide with the Top 5 of audience. $67 \%$ of professionals declare that they have increased investment in social networks compared to 2018. Facebook is the one that increases the most with growth rates of $55 \%$, Instagram $48 \%$, and quite far behind Twitter $23 \%$, YouTube 17\%, LinkedIn 10\%, and WhatsApp 7\%.

"Social Networks and the rest of the media coexist in harmony" as concluded in the Publicis Media Study. The contents of traditional media, TV, press, and radio feed each other with those of social networks, and people like the media to be complementary but, on the contrary, it has the disadvantage that by accessing multiple sources of information simultaneously, it can lead to attention deficit.

\subsection{The phenomenon of Influencers in Social Networks}

Both studies collect data on the phenomenon of influencers and their ability to prescribe brands and reach a younger audience that is difficult to access from other communication channels. According to the IAB, $58 \%$ of the professionals surveyed have hired the services of influencers and $87 \%$ are satisfied or very satisfied with the results.

It's important to differentiate a Youtuber from an influencer, although they are shareable figures, they are not the same. The former have a more positive image than the latter. 
Influencers have become fashionable, they are the most growing trend in the social environment, they have become references. Therefore, they have a certain social responsibility that can be positive if managed properly. They have become role models for many. For this reason, influencers should only generate content on topics that they know about and understand. In this sense, some question the rigor of the influencers' activity, given their lack of training on the topics they deal with on some occasions and their desire to gain followers only to obtain financial benefits, not out of conviction in their social work.

The popularization of the figure of influencer has led to the appearance of great diversity and proliferation of them. As a consequence, on the one hand, some contents have lost their originality, and, on the other hand, saturation provokes negative reactions and opinions towards them.

For their part, some think that YouTubers differ from influencers by making higher quality content since videos are more complex and complete than images, they allow them to deepen the topics covered. Youtubers are more informed and specialized people who have to generate a good flow of content on specific topics in the form of a video, in such a way that they get to create a community around that content of which they are specialists.

As in the case of influencers, people differentiate between YouTubers who generate content out of passion and those who do so for financial reasons. In a way, they have replaced bloggers, their figure is perceived as obsolete, both for the content they generate and for the way they expose it, to the point that many of them became YouTubers.

There is also a specialization of child YouTubers, although a priori it could be counterproductive for the youngest, the digital transformation could be changing these conceptions, so the existence of these profiles for children is not seen with bad eyes among users.

As the Publicis Media Study continues to collect, the main reasons why users follow influencers on social networks are

- Entertainment: Influencers distract them. They spend time browsing their lives and also laugh at their funnier content such as videos on Instagram Stories.

- Inspiration: Especially in the fashion sector, users follow influencers because of their style, because they notice their looks.

- Giveaways: Some users acknowledge following influencers who organize many giveaways.

- By inertia: Sometimes, some users begin to follow an influencer and, although later their content does not interest them as much as it did first, they continue to follow their profiles. 
According to the Publicis Media study, the most powerful social networks for influencers are YouTube and Instagram. The most followed topic is fashion, with people like Dulceida, Alba Paul, Paula Gonu, etc. There are also other influencers specialized in video games such as El Rubius and other topics such as Cooking and recipes, television and reality shows, makeup, or family.

But there are also active users on social networks who do not follow Influencers for different reasons: they are not credible because they know that brands are paying them and they do not want them to make money at their expense. They consider that they earn too much money for what they do and do not want to contribute to it, or they want to have their own ideas and not be carried away by those of influencers.

Among those who do not follow influencers, they do acknowledge following opinion influencers, that is, journalists and other experts on certain topics or global celebrities who also act as influencers, in part, because they promote their products, such as Kim Kardashian or model Emily Ratajkowski.

There are less-active users of networks who do not know any influencer or have any interest in them, while there are others who do not follow them, but know the most famous influencers because they appear on television shows or spots.

Without a doubt, this new figure has begun to be used massively by brands to promote their products and promotions through social networks. They are used in a similar way to the one that, before their appearance in the digital world after the democratization of content, celebrities, athletes, actors, and well-known and popular people were used in conventional media to promote brands.

\subsection{The perception of brands on Social Networks}

The use that brands and advertisers are making of social networks is collected annually. The latest study "VII Observatory of brands in social networks" carried out by IAB and published in 2019, has carried out an analysis about the use of the bestknown brands in each of the following categories: automotive, games and bets, food, beauty and hygiene, distribution, energy, finance and insurance, technology, telecommunications, travel, and government and politics.

This study clearly demonstrates how there are many brands present in the social environment with active profiles that are connecting with the consumer through these social environments. 


\section{Sectores y marcas estudiadas}
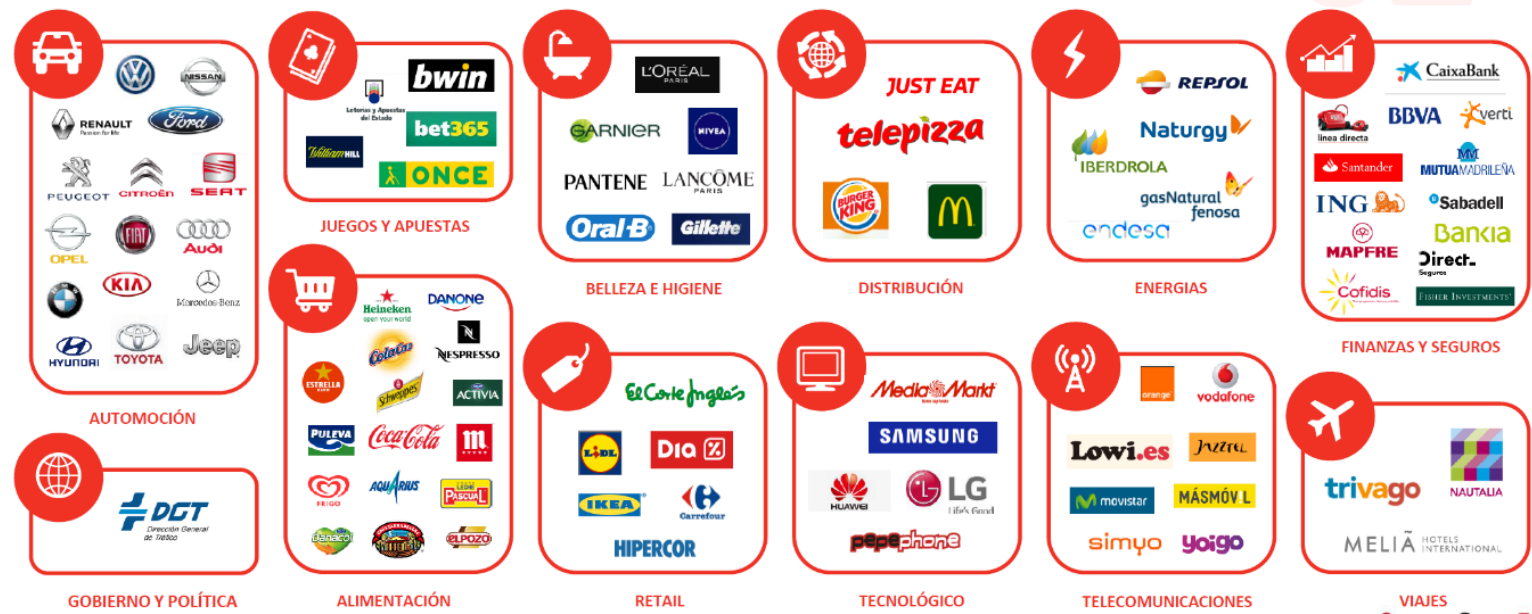

FINANZAS Y SEGUROS

Epsilon gestazioin

Image 14: Sectors and brands analyzed in the \#IABestudioMarcas Source: IAB Spain (2019)

To evaluate the use that brands make of social networks, several criteria are analyzed by category, brand, and social network: Community size, number of publications and interactions, engagement rates, percentage of virality, and efficiency.

There are many user communities in all the categories analyzed. Community is defined as the sum of the number of fans, followers, or subscribers of social networks. There are more than 52 million participants in communities in Spain. The Top 3 communities are occupied by the categories of distribution, technology, and distribution.

The publications, which are defined as the number of posts plus tweets, rose to more than 280,000 in the analyzed annual period. And the sectors in which the most publications were made are gaming and betting, telecommunications, and distribution.

The most popular interactions are with the distribution, distribution, and betting brands.

The engagement ratio, which is defined by the number of interactions plus the communities divided by the 12 months of the year, rises on average to $6.2 \%$ but with very marked differences between the analyzed social networks. While on Instagram, engagement is super high and reaches a ratio of $26.1 \%$, on Facebook is $3.9 \%$, on Twitter is $3.3 \%$, and on YouTube is $1.7 \%$. 
The percentages of virality collected by the number of shares rose to almost 2.7 million in the analyzed year with an average of 29,000 shares per brand. It must be taken into account that this data is only for two of the 4 social networks analyzed, Facebook and Twitter, because YouTube and Instagram do not have shared content.

To complete the observatory, the efficiency, defined as the number of interactions divided by the number of comments, is analyzed. Efficiency shows an average ratio of 102 per analyzed brand, with a great disparity by sectors from the highest such as distribution with a ratio of 2,042 to the telecommunications sector with 61 .

Below are the Top 3 ranking categories and the Top 3 brands in all aspects analyzed above. Distribution appears as one of the most active sectors in social networks and in almost all criteria it is in the Top 3, being one of the categories that use social networks the most due to its link to e-commerce by users to search for product recommendations and services and read comments from other users who have already tried it.

Games and Bets also appear in 5 of the 6 criteria analyzed in the Top 3 since they are the result of comments and opinions most of the time linked to sports.

The Government and Politics category appears in the Top 3 only in virality and engagement as a platform for vindication, opinion, and debate.

\section{Ranking TOP 3 categorías}

\begin{tabular}{|c|c|c|c|}
\hline & 1 & 2 & 3 \\
\hline COMUNIDAD & Retail & Tecnología & Distribución \\
\hline PUBLICACIONES & Juegos y apuestas & Telecomunicaciones & Retail \\
\hline INTERACCIONES & Retail & Distribución & Juegos y apuestas \\
\hline ENGAGEMENT & Juegos y apuestas & Energias & Gobierno y Políticas \\
\hline VIRALIDAD & Gobierno y política & Retail & Juegos y apuestas \\
\hline EFICIENCIA & Distribución & Juegos y apuestas & Viajes \\
\hline
\end{tabular}

Image 15: Ranking of Categories in the \#IABestudioMarcas Source: IAB Spain (2019)

Regarding the leading brands in the use of social networks, we see a diversity concerning the different analyzed categories, but it is clear that El Corte Inglés in the category of distributors, followed by Lidl and Bet365 in the Games and Betting category, occupy important places. 
Fernandez De Bordóns, B. y Niño González, J I. The consumer on social networks and brand perception analysis

\section{Ranking TOP 3 marcas}

\begin{tabular}{|c|c|c|c|}
\hline & 1 & 2 & 3 \\
\hline COMUNIDAD & tim & Gecorlefinglés & IKED \\
\hline PUBLICACIONES & Tofliliamnu & orenged & secorlefinglés \\
\hline INTERACCIONES & Gecorlefingless & bet365 & $x \rightarrow 00$ \\
\hline ENGAGEMENT & bet365 & IBERDROLA & ¿ONCE \\
\hline VIRALIDAD & Dia & $\stackrel{F}{F}$ & Gecorlefinglés \\
\hline EFIIIENCIA & 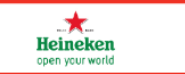 & Nispersso & ACTIVA \\
\hline
\end{tabular}

Image 16: Ranking of brands in the \#IABestudioMarcas

Source: IAB Spain (2019)

It is observed how users behave very differently regarding brands in each of the 4 networks analyzed. Thus, Facebook is the undisputed leader in the size of its Community with $69 \%$. Instagram (53\%) leads together with Facebook $(40 \%)$ the share of interactions and efficiency $(62 \%+31 \%)$ and leads the engagement share alone with $75 \%$ of the total. While Twitter alone leads the two remaining categories, publications (78\%) and virality (67\%).

\#IABestudioMarcas

\section{Cuota RRSS totales en España}
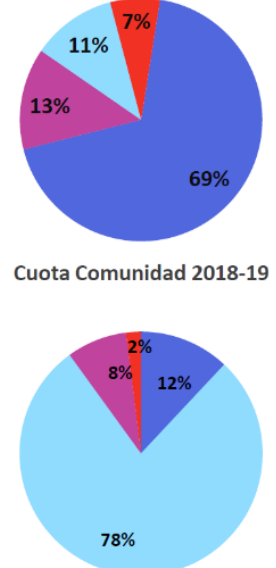

Cuota Publicaciones 2018-19

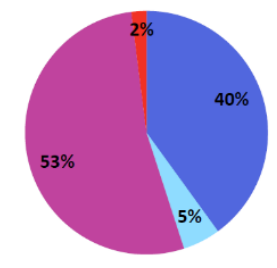

Cuota Interacciones 2018-19

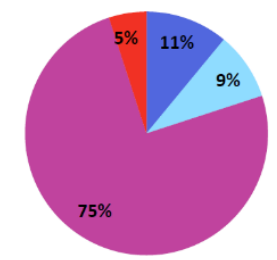

Cuota Engagement 2018-19

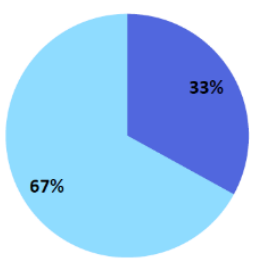

Cuota Viralidad 2018-19

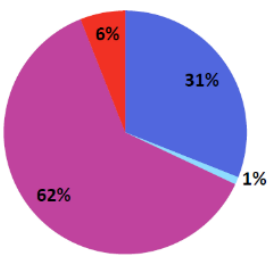

Cuota Eficiencia 2018-19 f Facebook

아 Instagram

Twitter

YouTube

Image 17: Share on Social Networks in \#IABestudioMarcas

Source: IAB Spain (2019)

It is also observed in the study how brands are not only generating activity in social environments on their own channels but that $43 \%$ of them come from profiles 
Fernandez De Bordóns, B. y Niño González, J I. The consumer on social networks and brand perception analysis

of influencers or brand amplifiers analyzed in the previous point. In them, new product launches, product giveaways to their audience, stories of consumption moments, and promotions of brand events are carried out.

The observatory also collects some best practices for the use of social networks:

1. Real-time marketing in the search for moments of connection with the user in which they can think about your product.

2. Content of value to improve the lives of users with tips, recipes, and other formulas like, did you know?

3. User participation with the brand through questions to the expert or giveaways.

4. Brand ambassadors in territories related to those of the brand.

5. Promote collaborations or marketing actions with other brands to reach a larger audience.

6. Authenticity and hyper-realism of the brands to not be perceived as advertising content.

7. Use of Instagram stories

8. Emotional content through real stories and good creativity.

9. Content strategy on YouTube like on a television show

10. Twitter as a second TV screen generating trends.

The IAB observatory that collects the activity of brands on social networks is a very powerful tool to learn about the virtues of these platforms to connect with consumers and undoubtedly a benchmark of the market to follow.

\section{CONCLUSIONS}

The different analyzed studies show how Social Networks have reached maturity and have earned a place in the daily activity of all Internet users. The data shows a heterogenization of social platforms that are no longer the patrimony of the youngest, but of all those who have the curiosity to know the opinions of others, the passion for self-expression and political or social demands, and the need to connect with their groups of friends or like-minded people. More and more Spaniards spend more time hooked on social networks and these have become a window to the outside world that a few years ago was monopolized by the television, press, magazines, and radio. The access to social networks from the mobile phone stands out and they consume them simultaneously with other media. We talk about the generation of the perennials, more digitally active, and not classified by sociodemographic, but attitudinal, criteria.

This phenomenon has undoubtedly reached commercial brands that increasingly use this channel to establish connections with consumers and have created their communities in their own profiles or through external channels managed by opinion leaders or influencers who, in some cases, become official brand ambassadors.

Social Networks are covering land in social communication, previously occupied by other traditional media. Thus, Twitter or YouTube have become a source of 
information competing with TV, the press, and radio, WhatsApp has become a virtual communication channel between groups of friends, replacing beers in a bar or the telephone contact between two people, and Facebook and Instagram have emerged as a meeting and socialization channel competing with social relationships in person. This happens with more intensity in situations of confinement, such as those that have been produced by COVID-19.

Although there are many social networks used in Spain, the analyzed studies show how there is a great difference in the audience levels between the Top 5 and the rest of the Social Networks. For this reason, advertisers are directing the marketing and advertising budgets of brands to the main networks used in Spain.

Social Networks have become in recent years one of the main digital communication channels for brands. According to the "Report on Advertising Investment in Digital Media in 2019", published by IAB Spain in April 2020, 25.6\% of the $€ 3,150$ million invested in digital advertising in Spain, are allocated to paid actions in social networks. These companies, with more than a quarter of digital advertising investment, have become the third most important digital channel after search engines (31.5\%) and display (30.7\%) and mark a distance from the next digital channel, which are classified with $8.2 \%$ of the investment. They are, therefore, a fundamental ally for advertisers in establishing effective connections with consumers.

Finally, Social Networks have also become a very rich source of information to get to know the consumer through social listening tools. It is possible to know the feelings, emotions, and intentions of people and take an X-ray of the mood of people, to decide the best strategy to establish effective connections with the consumer, at the precise moment in which they may be interested in knowing a product or service of a brand. It is, therefore, a very valuable source of information to obtain Insights from consumers and establish effective communication strategies for advertisers.

\section{Future lines of research}

We will have to continue to be very attentive to the evolution of the phenomenon of social networks. Like everything digital, it evolves rapidly with very significant changes that can dramatically alter the use of networks by users and advertisers

In contexts such as the current one, where a pandemic such as COVID-19 confines users to their homes and face-to-face social relationships are drastically reduced, it is necessary to research the role played by social networks and from what perspectives they can assume a surrogate role in physical relationships. Some networks like WhatsApp have increased group video calling services, developing new functionalities for users and allowing multiple connections in real-time. And in the last months of confinement, platforms that allow the establishment of video calls with hundreds of users such as Zoom have become popular, becoming the most used Social Network for holding virtual events. 
In this sense, it will be necessary to determine how to value the information shared by individuals in private social networks. Since there is an important difference between networks such as Twitter and YouTube where information is public and trends can be monitored with social listening tools, and other networks such as Facebook, Instagram, and WhatsApp where the information is shared in private networks of users to which brands cannot access.

From the regulatory point of view, it will also be necessary to be very attentive to the impact that the new European policies for the protection of the privacy of personal data may have on social platforms. The rules established by the European Data Protection Regulation, mandatory since May 2018 for all companies that manage and store personal data, are facilitating litigation against leading companies in this social environment, such as Facebook, and may end up changing the dynamics of the market as we know it today.

On the other hand, the introduction of artificial intelligence tools and virtual profiles or chatbots, to contact to offer customer service, can also substantially modify the communication codes and the objectives of users in the use of social media.

It is a very new world that has only just begun, in which changes occur every day. Therefore, it will be necessary to follow closely to monitor its evolution in the future of social communication for consumers and brands.

\section{REFERENCES}

AIMC (2015). Resumen Ejecutivo Nuevo Sistema de Clasificación Económica del EGM.

https://www.aimc.es/a1mcc0nt3nt/uploads/2018/05/resumen info clas socioeconomica.pdf)

Boyd, D. \& Ellison, N. (2007). Social network sites: Definition, history, and scholarship. Journal of Computer-Mediated Communication, 13 (2008) 210-230, 2008 International Communication Association, 211-212. https://doi.org/10.1111/j.1083-6101.2007.00393.x

Brunetta, H. (2013). Marketing digital ebook: Claves para implementar estrategias efectivas en redes sociales. RedUsers. Argentina.

Burgueño, P. (17 de mayo de 2020). Clasificación de redes sociales. https://www.pablofb.com/2009/03/clasificacion-de-redes-sociales/

Celaya, J. (2011). La empresa en la web 2.0. Gestión 2000. Madrid.

Erkan, I., \& Evans, C. (2016). The influence of eWOM in social media on consumers' purchase intentions: An extended approach to information adoption. Computers in Human Behaviours, 61, 47-55. https://doi.org/10.1016/j.chb.2016.03.003 
Fernandez De Bordóns, B. y Niño González, J I. The consumer on social networks and brand perception analysis

Godey, B., Manthiou, A., Pederzoli, D., Rokka, J., Aiello, G., Donvito, R., \& Singh, R. (2016). Social media marketing efforts of luxury brands: Influence on brand equity and consumer behavior. Journal of Business Research, 69(12), 5833-5841. https://doi.org/10.1016/j.jbusres.2016.04.181

IAB Spain (2019). "Estudio anual de Redes Sociales 2019". https://iabspain.es/estudio/? sft publicacion=2019,2018\& sft categora de estud io=redes-sociales

IAB Spain. (2019) Infografía de las Redes Sociales en España 2019. https://iabspain.es/estudio/? sft publicacion=2019,2018\& sft categora de estud io=redes-sociales

IAB Spain. (2019) Observatorio de Marcas en Redes Sociales 2019. https://iabspain.es/estudio/? sft publicacion=2019,2018\& sft categora de estud io=redes-sociales

IAB Spain. (2020) Inversión publicitaria en Medios Digitales Resultados 2019. https://iabspain.es/estudio/estudio-de-inversion-publicitaria-en-medios-digitales-3/

IAB Spain. Top tendencias digitales en España 2019. https://iabspain.es/estudio/toptendencias-digitales-2019/

Lee, J. \& Hong, I. B. (2016). Predicting positive user responses to social media advertising: The roles of emotional appeal, informativeness, and creativity. International Journal of Information Management, 36(3), 360-373. https://doi.org/10.1016/j.ijinfomgt.2016.01.001

Martinez, E. y Nicolás, M. A. (2016). Publicidad Digital. Hacia una integración de la planificación creación y medición.

Martínez, J., Noguera, J., y Grandío, M. M. (2011). Redes Sociales para estudiantes de Comunicación. UOC, Barcelona.

Publicis Media (2019). Descubriendo las redes sociales: Mapa del Consumo y Uso en España 2019. Estudio interno no publicado. https://www.reasonwhy.es/actualidad/estudio-uso-redes-sociales-publicis-media

Uribe Saavedra, F., Rialp Criado, J., Llonch Andreu, J. (2013). El uso de las redes sociales digitales como herramienta de marketing en el desempeño empresarial. Cuad. admon.ser.organ. Bogotá (Colombia), 26 (47), 205-231. 


\section{AUTHORS}

\section{Beatriz Fernández de Bordóns.}

Professional with more than 20 years of experience in marketing and digital communication. She has worked in consulting, launched an e-commerce platform in 1999, and has been a part of Publicis Groupe since 2000, where she has held various management positions in digital agencies in Spain and the United States. She has a degree in Business Administration from the Autonomous University of Madrid, a Law degree from the Complutense University of Madrid, and an MBA in Business Management and Administration from the ESCP-EAP Business School. She is currently doing her Ph.D. on "The use of data in the incremental improvement of digital advertising efficiency" at the Faculty of Information Sciences of the Complutense University.

BeaFBordons@gmail.com

\section{José Ignacio Niño González.}

Doctor in Advertising and Public Relations from the Complutense University of Madrid. Associate Professor (Department of Theories and Analysis of Communication of the Faculty of Information Sciences (UCM). Deputy Director of the Neuromarketing Laboratory, Neurolabcenter (UCM). Secretary of the Academic Committee of the Doctoral Program in Audiovisual Communication, Advertising, and Public Relations Member of the consolidated Research Group UCM "Creation and psychosocial and cultural effects of communication." Author of multiple articles in impact research journals in Spanish and English, book chapters, and book in the field of neuromarketing, communication, and health. In his professional career, his time in advertising agencies such as Tandem DDB and Saatchi \& Saatchi or projects as a founding partner in the area of communication and new technologies such as Interacting or More Than Game stand out.

josenino@ucm.es

Orcid ID: http://orcid.org/0000-0001-6940-2399 